\title{
ОПЫТ ПРИМЕНЕНИЯ БИОЛОГИЧЕСКИХ МИШЕНЕЙ В СКРИНИНГОВЫХ ИССЛЕДОВАНИЯХ
}

\author{
Н.М. Фаустова, М.В. Карлина, М.Н. Макарова, В.Г. Макаров \\ ЗАО «Санкт-Петербургский институт фармации», 188663, Россия, Ленинградская обл., \\ Всеволожский р-н, г.п. Кузьмоловский, ул. Заводская, д. 3, корп.245.
}

DOI: 10.19163/MedChemRussia2021-2021-66

E-mail: faustova.nm@doclinika.ru

Для успешного лечения различных заболеваний в последние годы получил широкое распространение мишень-ориентированный поиск синтеза активных субстанций (АФС) для разработки лекарственных средств (ЛС). Перспективным является поиск и создание ЛС, в том числе на основе комбинаций АФС, способных воздействовать на несколько биомишеней. При поиске АФС для лечения сахарного диабета 2 (СД2) типа фермент дипептидилпептидаза 4 (ДПП-4) - один из часто используемых маркеров при исследованиях in silico/in vitro. СД2 часто является прямым последствием воспаления поджелудочной железы. В качестве мишеней для оценки противовоспалительного действия in vitro использовали ферменты 5/15-липоксигеназы, циклооксигеназу-2 (ЦОГ-2), а также ЛПС-индуцированное фосфорилирование МАР-киназы р38. Для первичного скрининга in vitro в качестве источника потенциальных АФС были использованы экстракты из икры зелёных морских ежей. Этанольный экстракт (ЭЭИЕ), ингибировал активность двух ферментов ЦОГ-2 и ДПП-4 [1]. На основании результатов изучения состава ЭЭИЕ были получены синтетические субстанции, аналогичные природным компонентам. В результате скрининга были выбраны два соединения: трипептидамиристат (ингибитор ДПП-4 IC50=140 20 мкМ) и этиловый эфир тригидрокси2-гептеновой кислоты (агонист FPR2-рецепторов; селективный ингибитор

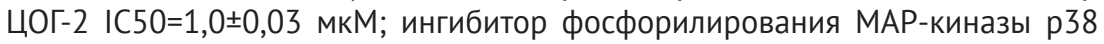

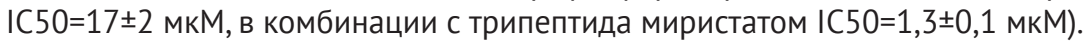

Для подтверждения биологического действия комбинации субстанций in vivo использовали моделирование СД на крысах (стрептозотоциновая модель) и соответствующую группу маркеров: определение активности ДПП-4, уровня глюкозы, С-пептида, гликозилированного гемоглобина в крови крыс; дополнительно определяли концентрацию FPR2-рецепторов в плазме крови и печени крыс. На основании результатов исследований in vivo было подтверждено предполагаемое антидиабетическое действие комбинации синтетических субстанций трипептида миристата и производного резолвина.

\section{Литература}

[1] O.N. Pozharitskaya, A.N., Shikov, I. Laakso Bioactivity and chemical characterization of gonads of green sea urchin Strongylocentrotus droebachiensisfrom Barents Sea// J. functional foods. 2015, Vol. 17, № P. 227-224

$$
-66-
$$

